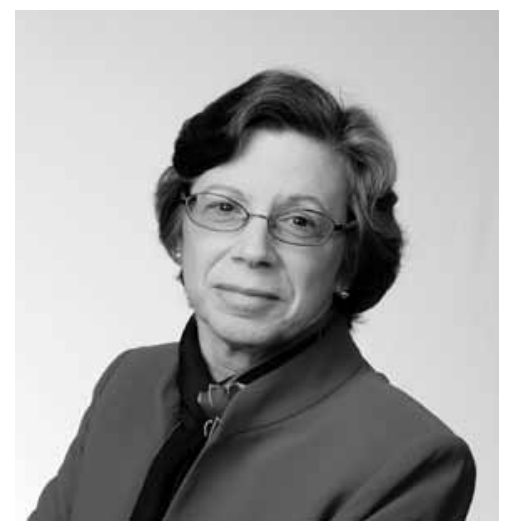

\title{
Association for Library Collections and Technical Services Annual Report 2009-10
}

\author{
By Mary Case, 2009-10 ALCTS President
}

$\mathrm{T}$

his year's primary goal of the Association for Library Collections and Technical Services (ALCTS) has been "Creating Our Future" as we have continued our focus on reshaping the organization to meet the needs of those working in the rapidly changing fields of technical services, collections, and preservation. At both the division and section levels, we have sought to decrease the barriers to performance and increase the opportunities for participation. Our effort is all the more urgent in the face of economic challenges that demand we provide products and services of significant value to attract and retain members. While this is an ongoing task, we have made significant strides in a number of areas this year.

\section{Reshaping Our Organization}

Member input gathered over the last several years through surveys, focus groups, and discussions led the ALCTS executive committee to conclude we need to reshape our organization. Our members expressed the following concerns:

- ALCTS no longer reflects the diversity of job functions performed by those employed in collections and technical services.

- Members are frustrated by competing and overlapping programming.

- Processes are slow and not always clear in part because of redundancy in governance.

The executive committee, with input from the board, worked this year to construct alternative organizational scenarios that we have now shared with the entire membership for comment. In developing the scenarios, we were looking at options to achieve the following goals:

- Members must be able to find a community of colleagues doing the same work or with similar interests.

- The structure and processes must be transparent.

- The structure must be flexible enough to respond quickly to emerging trends.

- The organization must provide opportunities for service and leadership.

We look forward to reviewing the feedback from the member survey and

Mary Case (marycase@uic.edu) is University Librarian, University of Illinois at Chicago. from the animated discussions at the 2010 ALA Annual Conference and plan to present a refined plan for a member vote sometime next year. 


\section{Bylaws Changes}

In the meantime, the division undertook a process to revise its bylaws so future changes resulting from reorganization would not be slowed by outdated and ambiguous documentation. While the Organization and Bylaws Committee accomplished most of its work in 2008-9 under the leadership of Dale Swensen, the bylaws were put to a membership vote in fall 2009. The new bylaws passed with an overwhelmingly positive vote.

\section{Expanding Continuing Education}

While working toward a reorganization of the division, the executive committee recognized a need and an opportunity to address continuing-education issues. In-person workshops were no longer drawing an audience unless attached to a conference, members were expressing concerns about travel support from their institutions, and the multilayered education committee structure of the division and sections slowed the move of new ideas and products to market. We decided that a change to the education committee structure could move forward before changing the entire organization and might serve as a model for streamlining other product-driven committees, such as the publication committees.

To this end, the ALCTS board approved the dissolution of the ALCTS Education Committee and the creation of a new Continuing Education (CE) Committee that began work in summer 2009. Chaired by Pamela Bluh, this committee has quickly coordinated a robust program of Web courses and webinars that complement programming at conferences. Web courses, offered by ALCTS for several years now, continue to be popular. These four-week modules cover acquisitions, electronic resource acquisitions, collection development and management, and new this year, preservation. Under development are courses in collections assessment, cataloging, and serials. With the energetic shepherding of CE members, sixteen webinars were offered this year, almost tripling the number presented last year. These webinars covered institutional repositories, cataloging of unusual formats, metadata, disaster planning and response, among other topics. The popular e-forums begun last year by then President Dina Giambi now have a coordinator, Kristin Martin, who is an ex-officio member of the CE Committee. Generally held monthly, these e-mail conversations continue to attract members and nonmembers, with more than one thousand participants on the e-forum list. We are grateful to the many members who participate in CE by developing the content for webinars and Web courses, who suggest topics, and who participate in and evaluate these events. We look forward to the CE Committee's assessment of its first-year lessons learned and, in particular, how the liaison relationships with the sections have worked.

\section{Section Restructuring Initiatives}

The division has not been alone in its focus on reshaping its structure. Several sections have been working to simplify their structures during the last several years. The Preservation and Reformatting Section (PARS) completed its transition this year to a slimmed down committee structure. Several topic-based committees were reconstituted as interest groups. The Collection Management and Development Section (CMDS) has decided to revise its mission and change its name to the Collection Management Section (CMS), which took effect after the 2010 Annual Conference. It has also reduced its committees from eight to six and converted three committees to interest groups. The Continuing Resources Section (CRS) has been streamlining by combining its Education Committee with its Research and Publications Committee. The new Education, Research, and Publications Coordinating Committee, with a new mission, will take effect with the 2010-11 appointments. The Council of Regional Groups (CRG), ALCTS's connection to its affiliate members, has proposed changing its status from a section-like structure to a division-level committee with a new name, Affiliate Relations Committee. We believe that the good work of CRG will be more visible and integrated with such a change.

\section{National Preservation Week}

ALCTS and its sections have undertaken many other initiatives during this year. One of the highlights was the first national Preservation Week successfully launched May 9-15. Initiated by PARS, Preservation Week is a collaborative effort involving the American Library Association (ALA), the Library of Congress, the Institute of Museum and Library Services, the American Institute for Conservation of Historic and Artistic Works, Society of American Archivists, and Heritage Preservation. Local libraries and other institutions were encouraged to use Preservation Week to offer events, workshops, and resources to highlight the need for preservation while sharing expertise to help individuals and communities preserve personal and shared collections. A webpage (www.ala.org/preservationweek) was developed to provide resources, post local activities and events (about thirty-five nationwide), and share participant stories. The ALA designed a poster and bookmark with the theme of the week "Pass it On," which were available for purchase by the 2010 ALA Midwinter Meeting. ALCTS events during the week included the pilot online course (Fundamentals of Preservation) and two free public webinars (Archival 101 and Mold Prevention and Remediation), together attracting more than seven hundred participants. Key participants in Preservation Week included the New Jersey State Library, Regional Alliance for Preservation, Federal Library and Information Center 
Committee, and National Digital Information Infrastructure and Preservation Program. Corporate sponsorship included Gaylord Bros., FamilyArchives.com, Archival Products, and the HF Group. A program (Pass it On: National Preservation Week) at the 2010 Annual Conference and a PARS working group will ensure that knowledge and participation in Preservation Week grows over the years. Congratulations to PARS and Preservation Week Task Force Chair Jeanne Drewes.

\section{New Members and Emerging Leaders}

With the initiative of both seasoned and new members alike, a New Members Interest Group was started this year. The group had its first formal meeting at the Midwinter Meeting under the energetic leadership of Keisha Manning and worked with the Membership and Leadership Development Committees to design the ALCTS 101 event at Annual Conference. We hope this new group will help new members find each other and learn about ALCTS at the same time.

ALCTS sponsored a participant in the ALA Emerging Leaders program again this year. Shilpa Rele (metadata librarian and the University of Miami) and her cohort chose an ALCTS proposal as their project. The group worked to help the Leadership Development Committee place content for new ALCTS leaders on the Web, using Web 2.0 technologies where appropriate. The group has solicited several brief videos from current ALCTS leaders to provide advice to their successors.

\section{Year of Cataloging Research}

During the fall, the ALCTS board approved a resolution to declare 2010 the Year of Cataloging Research. The resolution emanated from the ALCTS task force working on implementing recommendations from On the Record, the final report of the Task Force for the Future of Bibliographic Control commissioned by LC. ALA Council approved the recommendation at the Midwinter Meeting. A new website (http://faculty.washington.edu/acarlyle/yocr/index.htm) provides information and resources. The Cataloging and Classification Section (CCS) presented programming to encourage more research.

\section{Awards}

Among the many individuals honored by ALCTS this year at its annual award ceremony were Olivia Madison, dean of the library at Iowa State University, recipient of the Margaret Mann Citation; Michele Cloonan, dean and professor of the Graduate School of Library and Information Science at Simmons College, recipient of the Banks/Harris Preservation Award; Peggy Johnson, associate university librarian for Access Services at the University of Minnesota, recipient of the Ross Atkinson Lifetime Achievement Award; and Kelley McGrath, cataloging and metadata services librarian at Ball State University, recipient of the Esther J. Piercy Award.

\section{Programs}

ALCTS and its sections continued their tradition of offering many outstanding programs during the Midwinter Meeting and the Annual Conference. Programs addressed e-books, electronic resource management systems, Resource Description and Access (RDA), the strategic future of print collections, Preservation Week, converging metadata standards, social tagging, collection development in tough times, and many more. The President's Program at the Annual Conference featured Dr. Francine Berman, vice president for research at Rensselaer Polytechnic Institute, who spoke to an enthusiastic audience on the new role for libraries in shaping twenty-first-century research.

\section{Publications}

ALCTS published a number of new works this year. A Guide to Video Acquisitions by Mary Laskowski will be available later in 2010. Available online is the ALCTS/PARS Metadata Standards and Guidelines Relevant to Digital Audio and chapter 1 of the book Institutional Repositories: The Promises of Yesterday, the Promises of Tomorrow. This book, edited by Pamela Bluh and Cindy Hepfer, is an experiment for ALCTS, with chapters being made available for free online as they are ready. The first chapter was written by Greg Tanabaum. Once all chapters have been published, a print volume will be available for purchase. ALCTS is introducing a new online series of white papers focused on issues in the profession intended to stimulate thinking and debate.

The activities cited above are only a snapshot of the many achievements of the committees, sections, and interest groups that make up ALCTS. I am honored to have been given the opportunity to meet and work with so many wonderful, dedicated individuals both within ALCTS, in the other ALA divisions, and in ALA. Thank you for the opportunity. I look forward to continued progress on our important agenda under the leadership of next year's president, Cynthia Whitaker. 